\title{
Glass-Forming Ability and Properties of New Au-Based Glassy Alloys with Low Au Concentrations
}

\author{
Hai Guo ${ }^{1, * 1}$, Wei Zhang ${ }^{2, * 2}$, Chunling Qin ${ }^{3}$, Jianbin Qiang ${ }^{2}$, Mingwei Chen $^{3}$ and Akihisa Inoue ${ }^{3}$ \\ ${ }^{1}$ Graduate School, Tohoku University, Sendai 980-8577, Japan \\ ${ }^{2}$ Institute for Materials Research, Tohoku University, Sendai 980-8577, Japan \\ ${ }^{3}$ WPI, Advanced Institute for Materials Research, Tohoku University, Sendai 980-8577, Japan
}

$\mathrm{Au}_{40} \mathrm{Si}_{17-20} \mathrm{Cu}_{28-30} \mathrm{Ag}_{5-7} \mathrm{Pd}_{5}$ glassy alloys showed a wide supercooled liquid region of $42-53 \mathrm{~K}$ and a large reduced glass transition temperature of 0.568-0.605, indicating high stabilization of supercooled liquid and high glass-forming ability (GFA). The best GFA was obtained from $\mathrm{Au}_{40} \mathrm{Si}_{20} \mathrm{Cu}_{28} \mathrm{Ag}_{7} \mathrm{Pd}_{5}$ alloy, and a fully glassy sample with a diameter of $6 \mathrm{~mm}$ could be fabricated by copper mold casting. The bulk glassy alloys exhibited very low $T_{\mathrm{g}}$ of $400-424 \mathrm{~K}$, high fracture strength of over $1100 \mathrm{MPa}$, and corrosion resistance superior to SUS316L in $1 \mathrm{~N} \mathrm{H}_{2} \mathrm{SO}_{4}$ solution. [doi:10.2320/matertrans.ME200809]

(Received December 4, 2008; Accepted March 26, 2009; Published May 20, 2009)

Keywords: bulk glassy alloy, glass-forming ability, gold-based alloy, glass transition temperature, mechanical property, corrosion resistance

\section{Introduction}

Since the synthesis of bulk glassy alloys (BGAs) in multicomponent $\mathrm{Ln}_{-}{ }^{1)}$ ( $\mathrm{Ln}$ : lanthanide metal) and $\mathrm{Mg}_{-}{ }^{2)}$ based alloys by copper mold casting in 1989, much effort has been devoted to the development of a new BGA exhibiting high glass-forming ability (GFA) and other useful engineering properties. As a result, BGA systems have been widely extended to $\mathrm{Zr}-{ }^{3-5)} \mathrm{Fe}-,{ }^{6)} \mathrm{Pd}-{ }^{7)} \mathrm{Ti}-,{ }^{8)} \mathrm{Co}-,{ }^{9} \mathrm{Ni}-{ }^{10-12)}$ $\mathrm{Cu}_{-},{ }^{13-15)} \mathrm{Pt}_{-},{ }^{16)}$ and $\mathrm{Au}^{-}{ }^{-17)}$ based alloys. These BGAs are expected to be useful in a wide variety of applications, because they exhibit unique properties such as high strength, high elastic strain limit, high hardness, good soft magnetic properties, viscous flow workability in the supercooled liquid region, homogeneity on the nanometer scale, and excellent corrosion resistance. ${ }^{18,19)}$ For practical applications, BGA requirements include high GFA, good mechanical properties, high corrosion resistance, and low cost.

Recently, Schroers et al. ${ }^{17)}$ reported that the Au-based glassy alloys exhibited high GFA (maximum sample thickness of $5 \mathrm{~mm})$, very low glass transition temperature $\left(T_{\mathrm{g}}\right)$ of about $400 \mathrm{~K}$, large supercooled liquid region $\left(\Delta T_{x}=\right.$ $T_{x}-T_{\mathrm{g}}, T_{x}$ : crystallization temperature) of over $50 \mathrm{~K}$, and good processability. This combination of properties makes the alloys attractive for many applications, including electronic, medical, dental, surface coating, and superplastic formation. However, the alloys contained about 50 at $\% \mathrm{Au}$, leading to a high material cost. In addition, little is known about the mechanical properties or corrosion resistance of the Au-based BGAs. For broader engineering applications, as well as further scientific studies on the Au-based glassy alloys, it is important to reduce the Au content in the BGAs without detrimentally affecting their unique properties, and also to clarify their mechanical properties and corrosion resistance. In this paper, we report the formation, thermal stability of supercooled liquid, mechanical properties, and corrosion resistance of new Au-based BGAs with 40 at\% Au content in the Au-Si-Cu-Ag-Pd system.

\footnotetext{
${ }^{* 1}$ Graduate Student, Tohoku University

${ }^{* 2}$ Corresponding author, E-mail: wzhang@imr.tohoku.ac.jp
}

\section{Experimental Procedure}

Alloy ingots were prepared by arc melting mixtures of $\mathrm{Au}$, $\mathrm{Cu}, \mathrm{Ag}, \mathrm{Pd}$ and $\mathrm{Si}$ with purities of over 99.5 mass\% in an argon atmosphere. The alloy ingots were re-melted four times to ensure chemical homogeneity. The mass losses were measured for each ingot after melting and were less than 0.1 mass $\%$. The glassy alloy was produced by copper mold casting for bulk cylindrical rods with diameters of 2 to $8 \mathrm{~mm}$. The thermal stability of the glassy alloy was examined by differential scanning calorimetry (DSC) at a heating rate of $0.67 \mathrm{~K} / \mathrm{s}$. Mechanical properties were measured with an Instron testing machine. The gauge dimension of specimens was $2 \mathrm{~mm}$ in diameter and $4 \mathrm{~mm}$ in height for compressive test and the strain rate was $5 \times 10^{-4} \mathrm{~s}^{-1}$. The fracture surface was examined by SEM. Corrosion resistance was evaluated by electrochemical measurements in $1 \mathrm{~N} \mathrm{H}_{2} \mathrm{SO}_{4}$ solution open to air at room temperature. Electrochemical measurements were conducted in a three-electrode cell using a platinum counter electrode and an $\mathrm{Ag} / \mathrm{AgCl}$ reference electrode. Potentiodynamic polarization curves were measured at a potential sweep rate of $50 \mathrm{mV} \cdot \mathrm{min}^{-1}$ after opencircuit immersion for about $20 \mathrm{~min}$ when the open-circuit potential became almost steady.

\section{Results and Discussion}

For developing new Au-based BGAs with lower $\mathrm{Au}$ contents, we first examined the effect of substitution $\mathrm{Cu}$ for $\mathrm{Au}$ on the stability of supercooled liquid and GFA of a $\mathrm{Au}-\mathrm{Si}-\mathrm{Cu}-\mathrm{Ag}-\mathrm{Pd}$ alloy with 50 at\% Au. Figure 1 shows DSC curves of the melt-spun $\mathrm{Au}_{50-x} \mathrm{Si}_{17} \mathrm{Cu}_{23+x} \mathrm{Ag}_{5} \mathrm{Pd}_{5}$ ( $x=0$ to 15) glassy alloys. It is seen that the $T_{\mathrm{g}}$ increases gradually from 404 to $440 \mathrm{~K}$ with decreasing Au content from 50 to 35 at $\%$, while $\Delta T_{x}$ increases from 47 to $59 \mathrm{~K}$ with increasing $x$ from 0 to 5 and then decreases to $32 \mathrm{~K}$ with a further increase in $x$ to 15 . On the other hand, as the Au content decreases, the liquidus temperature $\left(T_{1}\right)$ increases, and multiple endothermic events are observed, indicating that this alloy series go far from the eutectic composition. Table 1 lists the thermal parameters and the critical diameters $\left(d_{\mathrm{c}}\right)$ of 


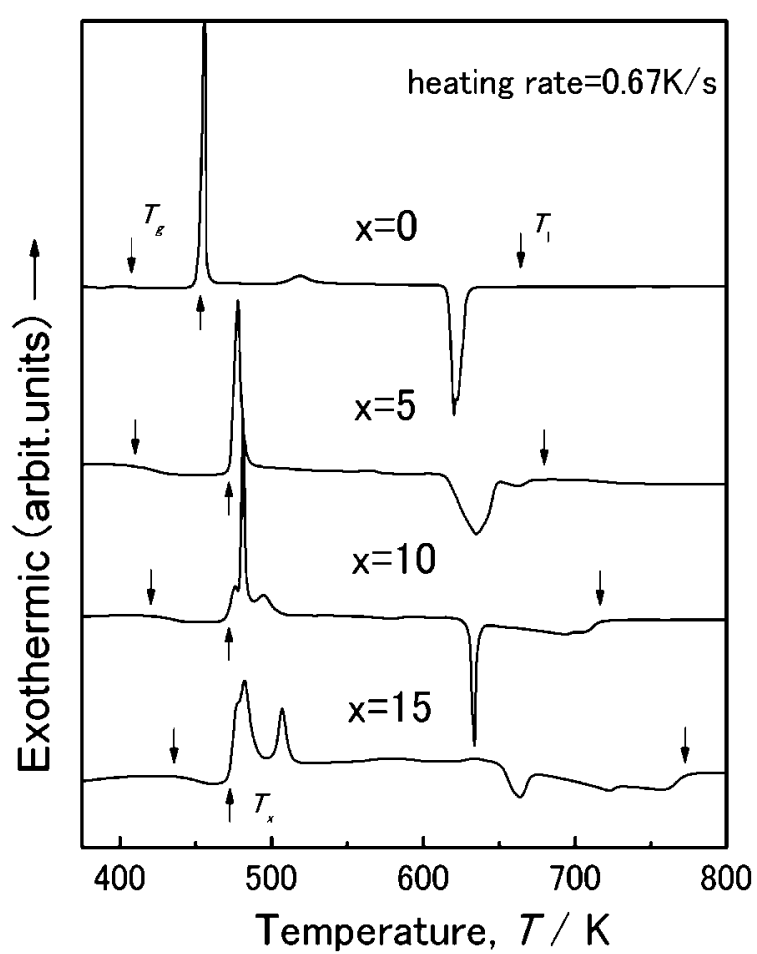

Fig. 1 DSC curves of melt-spun $\mathrm{Au}_{50-x} \mathrm{Si}_{17} \mathrm{Cu}_{23+x} \mathrm{Ag}_{5} \mathrm{Pd}_{5}(x=0$ to 15$)$ glassy alloys.

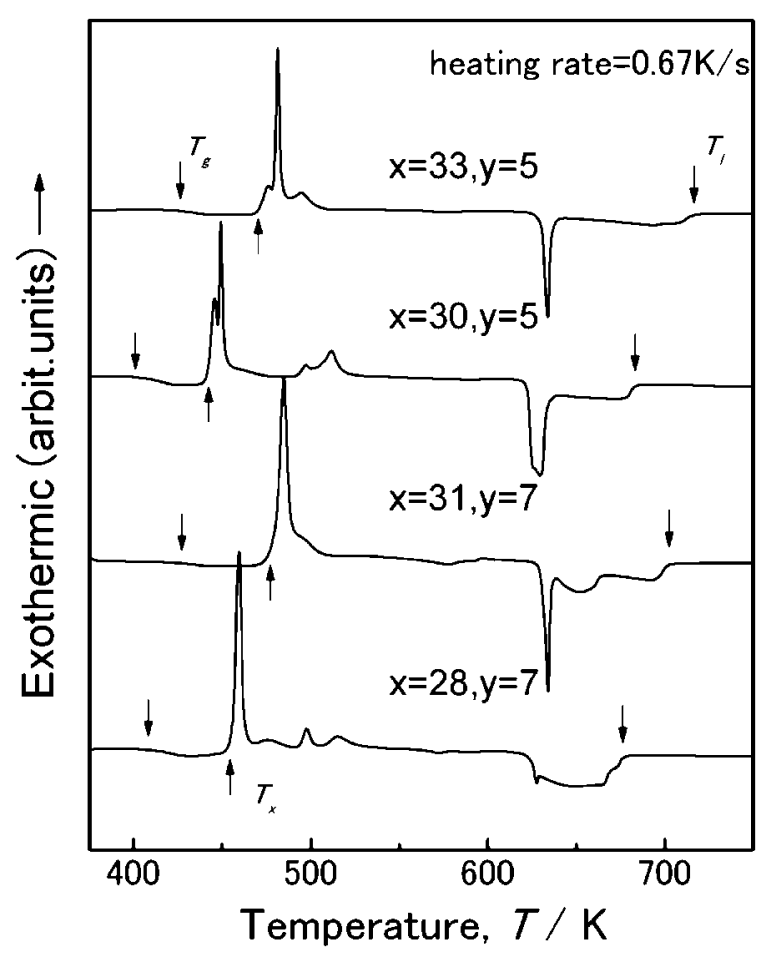

Fig. 2 DSC curves of melt-spun $\mathrm{Au}_{40} \mathrm{Si}_{55-x-y} \mathrm{Cu}_{x} \mathrm{Ag}_{y} \mathrm{Pd}_{5} \quad(x=30-33$, $y=5$ and 7) glassy alloys.

Table 1 The thermal parameters and the critical diameters of newly developed Au-based BGAs with lower Au contents.

\begin{tabular}{|c|c|c|c|c|c|c|}
\hline Composition (at\%) & $T_{\mathrm{g}}(\mathrm{K})$ & $T_{x}(\mathrm{~K})$ & $\Delta T_{x}(\mathrm{~K})$ & $T_{1}(\mathrm{~K})$ & $T_{\mathrm{rg}}$ & $d_{\mathrm{c}}(\mathrm{mm})$ \\
\hline $\mathrm{Au}_{50} \mathrm{Si}_{17} \mathrm{Cu}_{23} \mathrm{Ag}_{5} \mathrm{Pd}_{5}$ & 404 & 451 & 47 & 662 & 0.610 & - \\
\hline $\mathrm{Au}_{45} \mathrm{Si}_{17} \mathrm{Cu}_{28} \mathrm{Ag}_{5} \mathrm{Pd}_{5}$ & 413 & 472 & 59 & 677 & 0.610 & $>3$ \\
\hline $\mathrm{Au}_{35} \mathrm{Si}_{17} \mathrm{Cu}_{38} \mathrm{Ag}_{5} \mathrm{Pd}_{5}$ & 440 & 472 & 32 & 774 & 0.568 & $<2$ \\
\hline $\mathrm{Au}_{40} \mathrm{Si}_{20} \mathrm{Cu}_{30} \mathrm{Ag}_{5} \mathrm{Pd}_{5}$ & 400 & 442 & 42 & 683 & 0.586 & 3 \\
\hline $\mathrm{Au}_{40} \mathrm{Si}_{17} \mathrm{Cu}_{31} \mathrm{Ag}_{7} \mathrm{Pd}_{5}$ & 424 & 477 & 53 & 703 & 0.603 & 4 \\
\hline $\mathrm{Au}_{40} \mathrm{Si}_{20} \mathrm{Cu}_{28} \mathrm{Ag}_{7} \mathrm{Pd}_{5}$ & 409 & 456 & 47 & 676 & 0.605 & 6 \\
\hline
\end{tabular}

newly developed Au-based BGAs with lower Au contents. It is recognized that the reduced glass transition temperature $T_{\mathrm{rg}}\left(T_{\mathrm{rg}}=T_{\mathrm{g}} / T_{1}\right)$ decreases gradually from 0.610 to 0.568 with decreasing Au content from 50 to 35, leading to the decrease in GFA. However, the alloy with $40 \mathrm{at} \% \mathrm{Au}$ possesses sufficient GFA to form a bulk glassy sample with a diameter of $2 \mathrm{~mm}$.

We further optimized the Au-based alloys with 40 at\% Au for increasing the GFA, and found that the stabilization of supercooled liquid and GFA can be enhanced with small adjustment in $\mathrm{Au}_{40} \mathrm{Si}_{17} \mathrm{Cu}_{33} \mathrm{Ag}_{5} \mathrm{Pd}_{5}$ composition. Figure 2 shows DSC curves of melt-spun $\mathrm{Au}_{40} \mathrm{Si}_{55-x-y} \mathrm{Cu}_{x} \mathrm{Ag}_{y} \mathrm{Pd}_{5}$ $\left(x=30-33, y=5\right.$ and 7) alloys. Compared to $\mathrm{Au}_{40} \mathrm{Cu}_{33}$ $\mathrm{Si}_{17} \mathrm{Ag}_{5} \mathrm{Pd}_{5}$, the alloy with $x=28$ and $y=7$ shows a lower $T_{\mathrm{g}}$ of $400 \mathrm{~K}$, and the alloy with $x=31$ and $y=7$ shows a larger $\Delta T_{x}$ of $53 \mathrm{~K}$, which are similar to those of $\mathrm{Au}_{49} \mathrm{Ag}_{5.5} \mathrm{Pd}_{2.3} \mathrm{Cu}_{26.9} \mathrm{Si}_{16.3}$ glassy alloy. ${ }^{17)}$ In addition, all the alloys exhibit lower $T_{1}$, resulting in larger $T_{\mathrm{rg}}$. The glassy alloy samples with diameters of over $3 \mathrm{~mm}$ (see Table 1) were prepared, and the best GFA was achieved for $\mathrm{Au}_{40} \mathrm{Si}_{20} \mathrm{Cu}_{28} \mathrm{Ag}_{7} \mathrm{Pd}_{5}$ alloy, which had a $d_{\mathrm{c}}$ of $6 \mathrm{~mm}$.

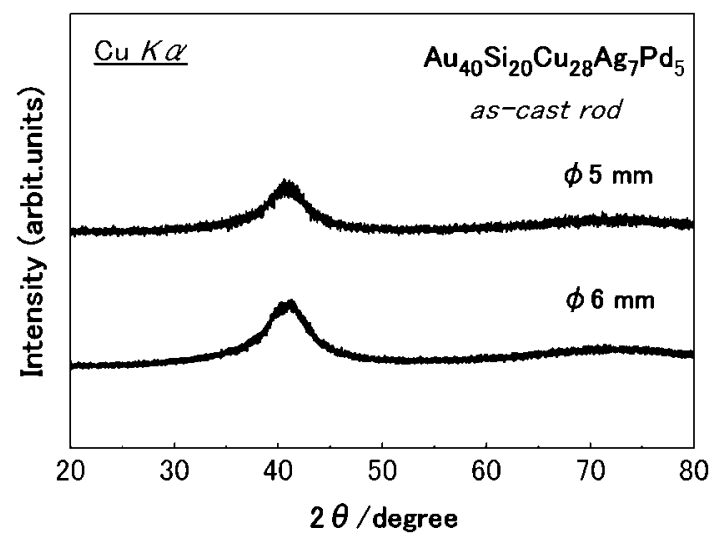

Fig. 3 X-ray diffraction patterns of as-cast $\mathrm{Au}_{40} \mathrm{Cu}_{28} \mathrm{Si}_{20} \mathrm{Ag}_{7} \mathrm{Pd}_{5}$ alloy rods with diameter of 5 and $6 \mathrm{~mm}$.

Figure 3 shows the $\mathrm{X}$-ray diffraction patterns of the as-cast $\mathrm{Au}_{40} \mathrm{Si}_{20} \mathrm{Cu}_{28} \mathrm{Ag}_{7} \mathrm{Pd}_{5}$ alloy rods with diameters of 5 and $6 \mathrm{~mm}$. All XRD patterns consist of only broad peaks, and no diffraction peak corresponding to a crystalline phase is seen, 


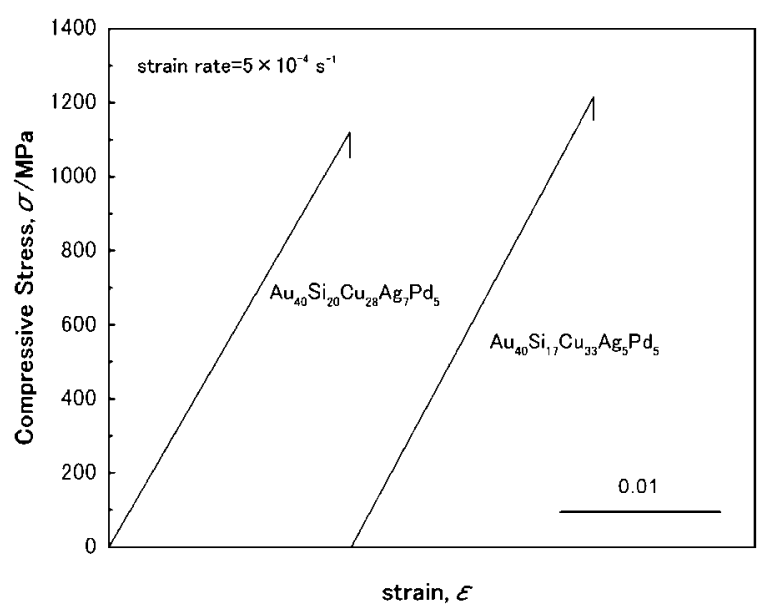

Fig. 4 Compressive stress-strain curves of as-cast $\mathrm{Au}_{40} \mathrm{Cu}_{28} \mathrm{Si}_{20} \mathrm{Ag}_{7} \mathrm{Pd}_{5}$ and $\mathrm{Au}_{40} \mathrm{Si}_{17} \mathrm{Cu}_{33} \mathrm{Ag}_{5} \mathrm{Pd}_{5}$ glassy alloy rods with a diameter of $2 \mathrm{~mm}$.

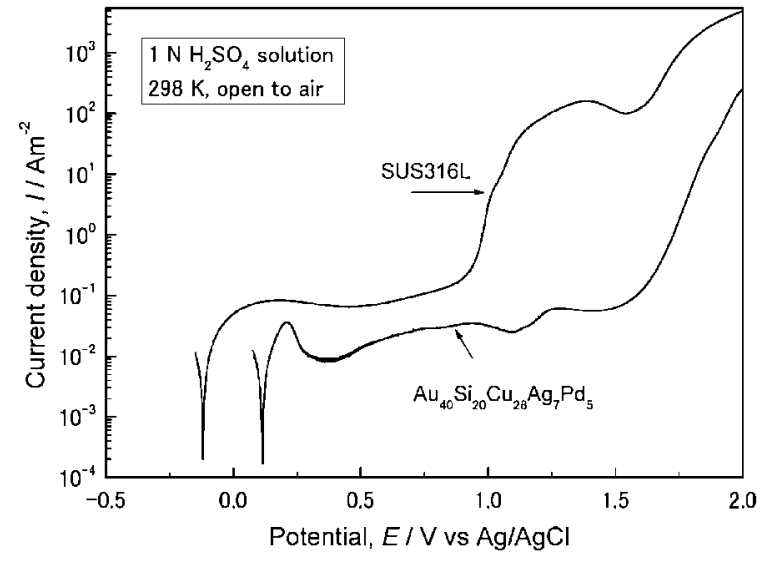

Fig. 6 Potentiodynamic polarization curves of $\mathrm{Au}_{40} \mathrm{Si}_{20} \mathrm{Cu}_{28} \mathrm{Ag}_{7} \mathrm{Pd}_{5}$ glassy alloy in $1 \mathrm{~N} \mathrm{H}_{2} \mathrm{SO}_{4}$ solution open to air at $298 \mathrm{~K}$. The data of the SUS316L stainless steel are also shown for comparison.

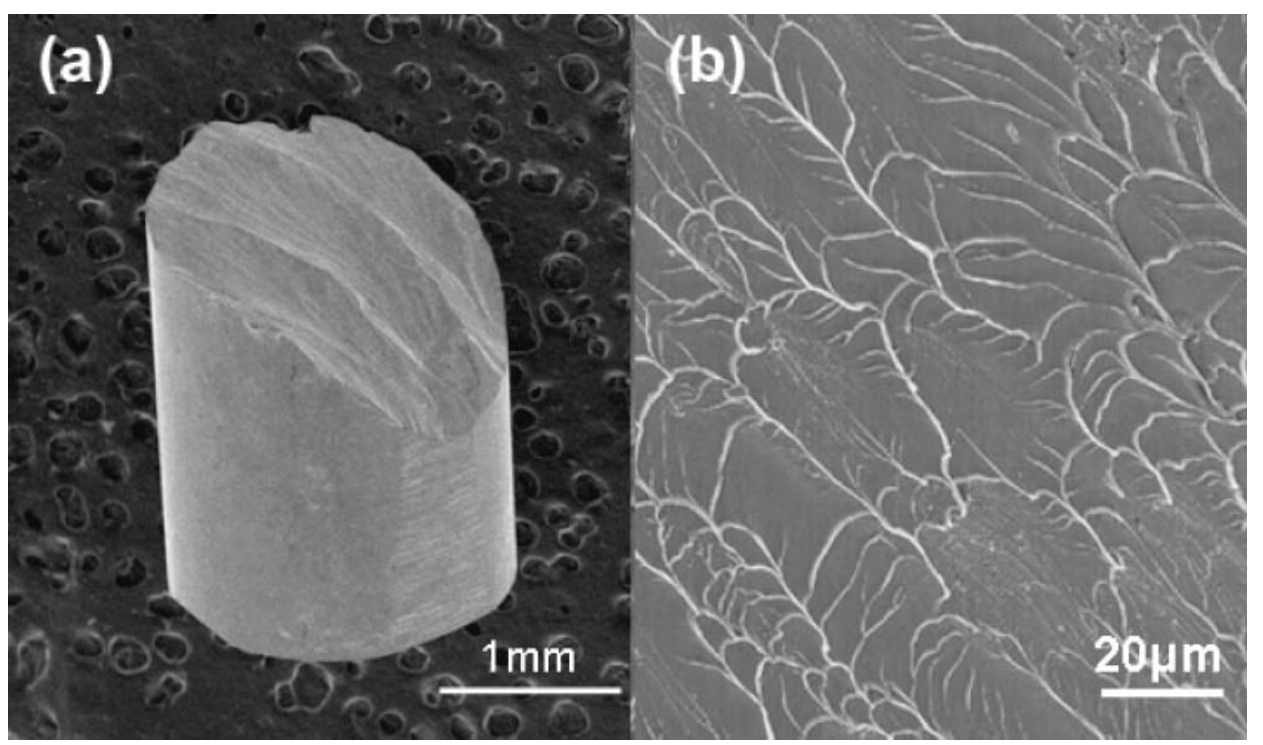

Fig. 5 Fracture surface appearance of the as-cast $\mathrm{Au}_{40} \mathrm{Si}_{20} \mathrm{Cu}_{28} \mathrm{Ag}_{7} \mathrm{Pd}_{5}$ glassy alloy rod with a diameter of $2 \mathrm{~mm}$.

indicating that the alloy rods are full glassy. Its GFA is higher than the previous data. ${ }^{17)}$ It has been noticed that the best GFA of the present $\mathrm{Au}_{40} \mathrm{Si}_{20} \mathrm{Cu}_{28} \mathrm{Ag}_{7} \mathrm{Pd}_{5}$ alloy composition is closed to a deep eutectic point (see Fig. 2). From a kinetic point of view, there are multiple ordered phases competing with each other for eutectic alloys in multi-component system, and the crystallization of the liquid requires simultaneous rearrangements of different species of atoms, which significantly suppress the kinetics of the crystallization process and thus promote glass formation. ${ }^{20)}$ In addition, a high $T_{\mathrm{rg}}$ above 0.60 implies that the viscosity of the supercooled liquid increases rapidly with decreasing temperature, leading to easy solidification of the supercooled liquid into a glassy solid state under the suppression of the crystallization reaction. ${ }^{18)}$

Figure 4 shows compressive stress-strain curves of the $\mathrm{Au}_{40} \mathrm{Si}_{20} \mathrm{Cu}_{28} \mathrm{Ag}_{7} \mathrm{Pd}_{5}$ and $\mathrm{Au}_{40} \mathrm{Si}_{17} \mathrm{Cu}_{33} \mathrm{Ag}_{5} \mathrm{Pd}_{5}$ BGAs. The glassy alloys exhibit good mechanical properties, i.e., compressive fracture strength, Young's modulus and Vickers hardness are $1120 \mathrm{MPa}, 75 \mathrm{GPa}$ and 340, respectively, for the former, and $1220 \mathrm{MPa}, 78 \mathrm{GPa}$ and 355 , respectively, for the latter. Although no distinct plastic strain is observed, the fracture of the samples occurred along the maximum shear stress plane, which is declined by about 45 degrees to the direction of applied load (see Fig. 5(a)), and the fracture surface consists mainly of a well-developed vein pattern typical to other BGAs with good toughness (see Fig. 5(b)). ${ }^{21)}$

Figure 6 shows the potentiodynamic polarization curves of the $\mathrm{Au}_{40} \mathrm{Si}_{20} \mathrm{Cu}_{28} \mathrm{Ag}_{7} \mathrm{Pd}_{5}$ glassy rod with a diameter of $2 \mathrm{~mm}$ in $1 \mathrm{~N} \mathrm{H}_{2} \mathrm{SO}_{4}$ solution open to air at $298 \mathrm{~K}$. The data of a SUS316L stainless steel sample are shown for comparison. The present BGA begins with a small active dissolution, followed by a passivation process with a very low passive current density of the order of $10^{-2} \mathrm{Am}^{-2}$. After the passivation, we can observe that the secondary passive region with a short potential domain occurs with further increasing applied potential. In addition, the $\mathrm{Au}_{40} \mathrm{Si}_{20} \mathrm{Cu}_{28}$ $\mathrm{Ag}_{7} \mathrm{Pd}_{5}$ glassy alloy shows much lower anodic current density than SUS316L stainless steel in the entire potential scheme, although the SUS316L is spontaneously passivated 
in this solution. As a result, the new Au-based BGA exhibits excellent corrosion resistance in $1 \mathrm{~N} \mathrm{H}_{2} \mathrm{SO}_{4}$ solution and its corrosion resistance is much better than that of the SUS316L.

\section{Conclusions}

The new series of Au-based BGAs with low Au concentrations had large $\Delta T_{x}$ of $42-53 \mathrm{~K}$, low $T_{\mathrm{g}}$ of $400-424 \mathrm{~K}$ and a critical sample diameter range of $2-6 \mathrm{~mm}$. The best GFA appeared around $\mathrm{Au}_{40} \mathrm{Si}_{20} \mathrm{Cu}_{28} \mathrm{Ag}_{7} \mathrm{Pd}_{5}$ alloy, which is close to a deep eutectic point in the multi-component system. The Au-based BGAs also exhibited high fracture strength of over $1100 \mathrm{MPa}$, and good corrosion resistance, superior to that of SUS316L in $1 \mathrm{~N} \mathrm{H}_{2} \mathrm{SO}_{4}$ solution. The high GFA, high stabilization of supercooled liquid, low glass transition temperature, good mechanical properties, and high corrosion resistance give the new glassy alloy excellent potential for future scientific and engineering applications.

\section{Acknowledgement}

This work was financially supported by Research and Development Project on Advanced Metallic Glasses, Inorganic Materials and Joining Technology from the Ministry of Education, Culture, Sports, Science and Technology of Japan.

\section{REFERENCES}

1) A. Inoue, K. Kita, T. Zhang and T. Masumoto: Mater. Trans. JIM 30 (1989) 722-725.

2) A. Inoue, A. Kato, T. Zhang, S. G. Kim and T. Masumoto: Mater. Trans. JIM 32 (1991) 609-616.

3) T. Zhang, A. Inoue and T. Masumoto: Mater. Trans. JIM 33 (1991) 1005-1010.

4) A. Peker and W. L. Johnson: Appl. Phys. Lett. 63 (1993) 2342-2344.

5) Q. S. Zhang, W. Zhang and A. Inoue: Mater. Trans. 48 (2007) 629-631

6) A. Inoue and S. G. Gook: Mater. Trans. JIM 36 (1995) 1180-1183.

7) A. Inoue, N. Nishiyama and T. Matsuda: Mater. Trans. JIM 37 (1996) 181184.

8) T. Zhang and A. Inoue: Mater. Trans. JIM 39 (1998) 1001-1106.

9) T. Itoi and A. Inoue: Mater. Trans. JIM 41 (2000) 1256-1262.

10) X. Wang, I. Yoshii, A. Inoue, Y. H. Kim and I. B. Kim: Mater. Trans. JIM 40 (1999) 1130-1136.

11) S. Yi, T. G. Park and D. H. Kim: J. Mater. Res. 15 (2000) 2425-2430.

12) T. Zhang and A. Inoue: Mater. Trans. 43 (2002) 708-711.

13) A. Inoue, W. Zhang, T. Zhang and K. Kurosaka: Acta Mater. 49 (2001) 2645-2652.

14) A. Inoue and W. Zhang: Mater. Trans. 43 (2002) 2921-2925.

15) W. Zhang and A. Inoue: J. Mater. Res. 21 (2005) 234-241.

16) J. Schroers and W. L. Johnson: Appl. Phys. Lett. 84 (2004) 3666-3668.

17) J. Schroers, B. Lohwongwatana, W. L. Johnson and A. Peker: Appl. Phys. Lett. 87 (2005) 061912-1-061912-3.

18) A. Inoue: Acta Mater. 48 (2000) 279-306.

19) Y. Saotome, Y. Fukuda, I. Yamaguchi and A. Inoue: J. Alloys. Com. 434-435 (2007) 97-101.

20) D. H. Xu, G. Duan and W. L. Johnson: Phys. Rew. Lett. 92 (2004) 245504-1-245504-4.

21) W. Zhang and A. Inoue: Mater. Trans. 45 (2004) 1210-1213. 